\title{
Het is zo stil
}

Corona legt alles stil in ons Brabantse verpleeghuis. Al een paar weken komt er geen bezoek meer binnen. We hebben - bijna onvermijdelijk - het coronavirus in huis en bewoners en personeel maken de besmetting door. Ons personeel kan goed ziek zijn, maar meestal volgt herstel. Dat geldt niet voor onze zo kwetsbare ouderen, die als ze besmet zijn in afzondering verpleegd worden. Ze begrijpen niet waarom de deuren dicht zijn en blijven. Waarom we in onze onherkenbare uitdossing veel weg hebben van maanvrouwtjes en -mannetjes, helemaal ingepakt in schorten en met handschoenen. En wie herkent nog een menselijk gezicht achter de mondkapjes en veiligheidsbrillen? Dat het nodig is, weten we. In korte tijd leren we corona kennen, een virus dat zich in vele gedaanten aandient en bij ouderen vaak aspecifiek. En meedogenloos.

\section{Aan het eind van deze week lukt het me niet meer}

Vandaag heb ik weer een familie moeten bellen dat we vanwege de situatie een uitzondering maken voor bezoek. Dat is slecht nieuws. Het betekent dat we inschatten dat iemand het niet gaat halen. Bezoek aan je dierbare man, vrouw, vader, moeder, broer of zus kan alleen om afscheid te komen nemen. Sommige familieleden durven niet, uit angst om zelf besmet te worden. Anderen komen wel en worden dan ook in het pak gehesen. Advies is om niet te kussen, maar met je handschoenen aan kun je iemand wel aanraken.

Een dochter is deze week toch bij haar stervende vader in bed gekropen. Hij is rustig gestorven, in haar armen. Een zoon neemt ook namens zijn moeder afscheid. Met de mobiele telefoon laat hij haar stem horen aan de stervende echtgenoot. $\mathrm{Zij}$ is zelf over de 90 en kwetsbaar; ze durft niet meer. Twee

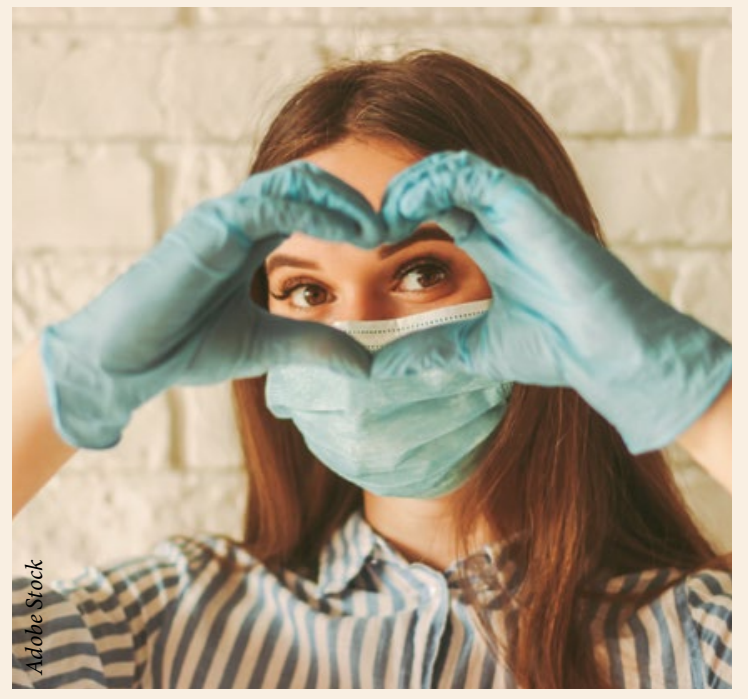

zussen zwaaien door het raam naar hun stervende broer; binnenkomen is te gevaarlijk.

Afstand houden is het devies. Aan het eind van deze week lukt het me niet meer. Weer iemand verloren. De man die zo prachtig kon tekenen en pianospelen is er niet meer. Voor hem was een piano op de afdeling gezet, waar hij hele concerten ten beste gaf. Ook in het restaurant, nu al weken leeg, kon hij zitten spelen en dan stond iedereen even stil. Alzheimer liet dat talent ongemoeid. Voor het huis dicht ging, was zijn vrouw dagelijks op de afdeling. Nu heeft ze haar man na mijn telefoontje niet meer alleen gelaten. Bijna twee dagen is zij in beschermende kleding aan zijn zijde gebleven. Aan het begin van de avond ben ik nog gaan kijken en twee uur later kom ik om te schouwen.

Daar staan we dan, bij zijn bed. We zijn allemaal helemaal ingepakt. Het is zo indringend stil. Hoezo afstand? Ik kan het niet en sla een arm om haar heen. We houden elkaar vast, we huilen. Om wat hier gebeurt, om wat om ons heen gebeurt. Om een afscheid in eenzaamheid. Om de troost die je iedereen gunt, die zo steunend kan zijn als veel mensen kunnen delen in je verlies. Afstand en nabijheid: het contrast is nog nooit zo schrijnend geweest. •
Door Mechtild Wijdeveld

Mechtild Wijdeveld is specialist ouderengeneeskunde en kaderarts palliatieve zorg. 